\title{
Angela Thody \\ Followership in educational organizations: a pilot mapping of the territory
}

\author{
Published: Leadership and Policy in Schools, 2003 Vol 2, No 2 pp 141-156
}

For discussion, or offers of your schools to host research on followership, or for more information about the author see:

www.angelathody.com

Emeritus Professor Angela Thody, Centre for Education Research and Development

University of Lincoln, Brayford Campus, Lincoln, LN6 7TS

Phone: 01522886071

Email: athody@lincoln.ac.uk/ angelathody450@hotmail.com

Abstract: A new lexicon of followership terms is suggested to develop this innovative area of research, helping to recognize that both our followership and leadership roles are important to organizational success.

Keywords: follower; leader; schools; business; education management.

\section{Introduction}

This article debates the little researched area of followership, seeking reactions to a lexicon of follower descriptors developed by the author. It contributes to the emergence of followership in educational administration, management and leadership practice and research (Thody, 1994, 1997, 2000, 2001). To make a more extensive understanding of followership easier, this article discusses routes to acceptability for followership, proposes the first lexicon for education followership and reflects on the importance of followership.

Followership exists in all educational organizations and in any phase of education or other business. Each role in an organization includes some following and some leading. Generally, the nearer one is to the top of a hierarchy, the fewer are the followership elements and, conversely, the nearer one is to the base of a hierarchy, the more will be the followership elements. The extent of followership will vary according to different projects, personalities, contexts and how other people decide to perform their roles. Followership is as natural as leadership since 'the proclivity to follow...exists, at least latently, in every human being’ (Gardner, 1997: 34). It is also as important as leadership.

Most of the few other writers and researchers on followership see it as only having a life that is determined by leadership. In contrast, this author hypothesises that followership has a life of its own too. This 'life' is significant to in its effect on leaders and on other followers. Followers are as much independent as leaders; what they do is at least as much an outcome of their personalities, their positions, their purposes and their own planning, as it is of leadership.

\section{Methodology}

The author first sought others researching followership. The search was thorough, wideranging and long but yielded only 231 sources $^{1}$, a tiny figure in comparison with the tens 
of thousands of sources on leadership. Table I shows how few followership studies exist and the lack of both primary research and of a focus on education.

Table I: Literature on Followership

\begin{tabular}{|l|c|}
\hline References & $\mathbf{n = 2 3 1}$ \\
\hline Using the words ' follower', 'non-leader', \\
'subordinate' or 'member' in their titles & 41 \\
\hline \multicolumn{1}{|c|}{ Of these 41, } & 3 \\
a) books & 18 \\
b) research studies & 22 \\
c) approach followership as a means of \\
improving or understanding leadership & \\
& \\
\hline Of the 18 research studies, & \\
$\mathrm{n}$ in educational contexts & 12 \\
\hline Of the 12 research studies in educational \\
contexts, \\
$\mathrm{n}$ using US university students as subjects & 10 \\
$\mathrm{n}$ in a US school & 1 \\
$\mathrm{n}$ in English schools & 1 \\
\hline
\end{tabular}

Followership primary research has used university, business or military contexts, largely USA and quantitative (Holmes et al 1980; Valikangas and Okumura 1997; Volgelaar and Kuipers 1997; Eden et al 2000). Literature on middle management and deputy school principals was searched but virtually all concern how to operate as leaders not as followers. The scant literature stimulated the author's gradual creation of a followership lexicon (Table II below), refined as the author garnered informal reactions to her various articles, conference presentation and lectures.

Opportunity populations of academic and practitioner conference audiences in 2002 pilot tested the lexicon. Their responses to questionnaires issued and collected at the conferences both confirmed and refined it. The conference audiences were 131 from eight countries at an international meeting in Sweden, (61\% Swedish) and twenty-six at a conference in England. Of the 157, 111 were school principals, deputies or senior teachers; twenty-four university staff ranged from $\mathrm{PhD}$ students to Associate Deans; ten held various levels of seniority in local, central or regional governments and the remainder were consultants.

These had to think about one/two work colleagues who were legally their subordinates and whom they considered to be, first, effective workers and secondly, ineffective workers. They then chose words to describe them from the author's followership lexicon and were asked to list any additional words in English or other languages that are used to indicate 'followers' or 'followership'. While no claims can be made that the audiences were representative samples, their views were helpful in confirming that early revisions to the vocabulary were proceeding appropriately, in suggesting an order of preference for followership descriptions, some additional possible words for followers and in formulating a more sophisticated questionnaire for later research. 
Before these outcomes are discussed further, the acceptability of the word 'followership' is debated.

\section{Finding routes to followership acceptability}

A key to gaining acceptance for followership as a legitimate and important area for study has seemed to lie in finding substitute words. This is because in English culture, followership has negative connotations of 'followersheep' and followership. No-one wants to be regarded as one who follows blindly like sheep nor do people in the egalitarian twenty-first century perceive themselves as of lower status to others. Weakness is seen as synonymous with following (Fullen, 1995, 23) and as failure to become a leader (Ouston, 1993).

The humour and anger which greeted the author's early conference presentations on 'followership' in the mid 1990s demonstrated followership's lowly status so the author adopted the subterfuge of 'non-leader' to persuade reviewers and audiences that followership is serious (Thody, 2001). Other authors found the same; few used 'follower' in article titles. Others disguised followers as 'subordinates' (Atwater et al, 1995), 'members'(Gemmil and Oakley, 1992), less expert peers (Gronn, 1996), nonleaders and observers (Meindl, 1990), non-managers (Engels, 1997, 26), audience (to the leaders as actors) (Gardner and Avolio 1998), 'stewards...or partners' (Petersen and Beekly, 1997) and 'contributors' (Williams, 1998).

This substitution denies the reality that followership exists where a person in an organization has someone (or a group) legally superordinate. All of us have to adjust to, accept, support or otherwise relate to, those performing leadership activities who have the right, or power, or influence to lead us. Each of us is both follower and leader.

The acceptance of followership depends, however, on more than just semantics. Schools today exhibit 'distinctive general homogeneity' (Williams, 1998, 8) apparently conducive more to egalitarian collegiality than to followership hierarchies. In England, for example, teaching staff are legally hierarchically distributed but have similar intelligence, educational achievements and qualifications and one of the shortest teachers' pay scale ranges in Europe. Administrative staff increasingly also have similar backgrounds and attitudes (O’Sullivan, Thody and Wood, 2000; Ellis 2003). Shared leadership is regarded as morally just and intrinsically valuable (Wallace, 2001:154).

This climate seems antithetical to followership but other factors offset it:

- External stakeholders enforce school bureaucratic hierarchies (Simkins, 1999; Wallace, 2001:165) especially in England's self-managing schools since the mid1980s (Evetts, 1993) with increased pay differentials between principals and other staff.

- Collegiality appears to be a desired, rather than an actual situation in schools, it is much criticized and conflicts with human nature (Bennett et al, 1992, 10; Gardner, 1997, 24; Brundrett, 1998).

- Current structural interpretations offer scope for followership too in, for example, the management of influence (Madison et al, 1980), the construction of shared meaning (Ferris et al, 1989), the achievement of aims not sanctioned by the 
organization (Mintzberg, 1985; Furnham, 1997) and the complex decision making that determines the relative power of those involved (Bush, 1995, 74-77).

- Theoretical doors to followership's entrance include Gronn's concept of 'conjoint agency' (2000:308), the 19802/90s teams and empowerment movements (Wallace and Hall, 1994; Wallace, 2001) and anti-leadership nihilism (Miner 1975; Lakomski, 1998).

\section{Exploring the territory: naming the new discoveries}

The author developed her own lexicon for followers (Table II) in educational organizations, having discovered that existing ones were for business or other contexts and contained mainly negative words (Bucholtz and Roth, 1987; Kelley, 1988 and 1992; Meindl, 1990; Chaleff, 1995; Brown and Thornborrow, 1996; Boyd and Taylor 1998; Nelson et al, 1998; Robbins and Finlay, 1998; Conger, 1999; Sevier, 1999). Such negativity is regarded as 'dangerously misleading' even by authors who are themselves negative (Brown and Thornborrow, 1996: 5). The author's lexicon used some other authors' terms which seemed suitable for transfer to education, added new ones and categorized the descriptors into:

a) holistic personality types - basic, largely innate, follower characteristics, describing general behaviours mainly, but not entirely, irrespective of the type of leader(s) with whom they are working or of their organizations' climate.

b) specific roles. Any personality type follower may perform one, or combine several, of these roles and/or select them as appropriate to the organizational context, type of leadership encountered or the personality of the follower. A leader may consciously or subconsciously direct followers into specific roles and there could be training for such roles

Both types and roles were each grouped as either positively effective or negatively effective $^{2}$. The author deliberately did not design a category of 'ineffective' followers since this would infer that followers are unimportant to the success or failure of an organization. Followers, however, always impact on their organizations.

The lists in Table II were originally presented alphabetically to the conference audiences. Their questionnaire responses indicated acceptance for the proposed vocabulary but the numbers selecting each descriptor provided an indication of each word's popularity so the alphabetic order of the list was changed to reflect these. Respondents' proposals for additional words for followership (predominantly negative) have been added to Table II in italics to distinguish them from the original list.

\begin{tabular}{|l|lc|}
\hline \multicolumn{3}{|c|}{ Table II: Thody's typology of followers } \\
(questionnaire respondents' additions in italics; \% to the nearest whole number)
\end{tabular}




\begin{tabular}{|c|c|c|c|}
\hline Interdepende & $8 \%$ & Toxic Handler & $9 \%$ \\
\hline Transactiona & $6 \%$ & Second in com & mand \\
\hline English & & Rescuer & $7 \%$ \\
\hline Puller-togeth & er, Opportunist, Crew, Those in the & Muse & $7 \%$ \\
\hline trenches & & Resnatronic & $4 \%$ \\
\hline Swedish & & & \\
\hline Medverkande & Participator & English & \\
\hline Medfoljare & Partner-Co-follower & Supportive cha & Ilenger, henchman \\
\hline Kompanjon & Equal working partner & Swedish & \\
\hline Folje & Follows 'king or queen' & Medhjalpare & Assistant/helper \\
\hline Stodjare & Supporter & Medarbetare $C$ & o-worker/Co-operator/Supporter \\
\hline Medansrang, & Co-responsible & Vapenohagare & One who carries your weapons \\
\hline$\underline{\text { Zulu }}$ & & Tross & Military team/the maintenance troop \\
\hline Amalunga & Team members & Larjunge & Like Jesus follower - Acolyte \\
\hline Abalingani, & Partners & Ugandan & \\
\hline German & & Omuweereze & Servant (in the biblical sense) \\
\hline Mitarbeiter, & Co-operator/Co-worker & $\underline{\text { Slovakian }}$ & \\
\hline Loyaler mital & beiter, Loyal co-worker & & Shadow \\
\hline & $\mathrm{n}$ responses $=348$ & & $\mathrm{n}$ responses $=321$ \\
\hline Negatively $E$ & ffective Follower Types & Negatively Eff & fective Follower Roles \\
\hline Alienated & $14 \%$ & Communicatio & n distorter \\
\hline Isolated & $12 \%$ & Saboteur & $28 \%$ \\
\hline Passive & $11 \%$ & Toxic creator & $26 \%$ \\
\hline Dependents & $10 \%$ & & \\
\hline Observers & $9 \%$ & & \\
\hline Reluctant-res & stive & & \\
\hline Sheep & $8 \%$ & & \\
\hline Machiavellia & $7 \%$ & & \\
\hline Plateaued & $7 \%$ & & \\
\hline Survivor & $7 \%$ & & \\
\hline Yes people, $\mathrm{c}$ & ependent, sycophant 7\% & & \\
\hline English & & English & \\
\hline Absent-minde & d, Perspective changer, Critical, & $\overline{\text { Floater, }}$ & \\
\hline Distrustful, $D$ & isorganised, Unesteemed, & Reluctant & \\
\hline Disillusioned & Limiter (limits involvement or own & Holding-role & \\
\hline skills negativ & ly), Lazy, NATO (No Action Talk & Non-communic & rato \\
\hline Only), Hange & rs-back, Traditionalist, Dependent & $\underline{\text { Swedish }}$ & \\
\hline survivor, Self & serving, Narrow-viewed, Incompetent, & Motarbetare & Against-worker \\
\hline Lemming & & Stovelslickare & Boot-licker \\
\hline Swedish & & Vorslickare & Ass-licker \\
\hline Medlopare & Co-runner/passive follower & Efterapare & Duplicator \\
\hline Ryttare & Rider & & \\
\hline Papegoja & $\begin{array}{l}\text { (Bird) always repeats what the last } \\
\text { person said }\end{array}$ & & \\
\hline$\underline{\text { Slovakian }}$ & & & \\
\hline Oportunista & Opportunist & & \\
\hline & $\mathrm{n}$ responses $=359$ & & $\mathrm{n}$ responses $=159$ \\
\hline
\end{tabular}

\section{Positively Effective Follower Types}

Active-passives - loyal and active supporters of leaders' decisions they like rather than of the leaders themselves; if they don't like decisions, they will be passive supporters neither opposing nor refusing to act. They are ruled by self-defined rationality for organizational needs. 
Entrepreneurs cope well in the businesses which England's educational organizations have become. Entrepreneurs are independent companies within their institutions.

Independents act on their own initiative, making responsible contributions to the well being of the organization without being asked to do so.

Exemplary/exceptionals support and work closely with leaders, participate actively in decision making, are willing/able to question and critique leaders' ideas, think independently, are energetic and assertive risk-takers and self-starters.

Loyalists logically justify their support for leaders before granting their quietly determined and unwavering loyalty.

Interdependents co-operate, assist, support, unite with and care for leaders with whose ideas they are closely congruent, almost interchangeable.

Transactionals acknowledges the use of delegated power by the follower (Beatty and Lee, 1992), the importance of lower-level exchanges (Hoskins, 1988) and subordinate perceptions of subordinate strategic choice (Pratt, 1984, 304).

\section{Positively Effective Follower roles}

Co-ordinators are elbow joints like middle managers whose job is where horizontal and vertical lines meet on the organizational matrix. Co-ordinators mediate, negotiate and interpret connections between strategic and operational levels (Steven and Woolridge, 1997).

Aspirant, mentee, apprentice are all leadership trainees roles who work to acquire leadership skills. They will be either very close to the leader in order to make a good impression and use learning opportunities or very far from the leader from nervousness in the presence of greatness, from frequent attendance on training programmes or because they do not want to appear 'pushy'.

Disciples teaching and interpret for others what they have learnt from the leader.

Gatekeeper-filters select which the information/problems/challenges/requests coming to leaders will go to them. They are loyal and organizationally knowledgeable; their value in reducing the burden on the leader is unquestioned.

Sidekicks, partners, comrades either have no official role in the organization, or assume a semi-official role. Sidekicks usually accompany the leader physically but are officially invisible. On this rests their helpfulness; they have little vested interest in the leader's own role but help the leader to make contributions.

Toxic Handlers are altruistic, 'heading off' trouble before it ever reaches the leaders. Toxic handlers sense problems arising and cure then before the leaders have to deal with them or even hear about them (Frost and Robinson, 1999).

Seconds-in-command, a military analogy, have a known, clear and accepted place for which the follower wants and maintains the boundaries. These followers suppress in 
public any differences of opinion with the leader, consciously develop skills which the leader does not have or does not chose to have and transmits as accurately as possible leaders' views to other followers.

Muses suggest ideas, or provide catalysts for ideas, but allow the leader to take credit for them (Berg, 2001)

Rescuers are 'otherwise unexceptional individuals who, during the Nazi era, risked severe penalties as they helped those whom they considered to be unfairly singled out for persecution' (Gardner, 1997, 35). For schools in exception circumstances (such as English schools graded as 'failing') the rescuer would be the follower who supports the principal who seems destined to be dismissed.

Resnatronics are deputies who either cannot achieve principalship or who elect to remain deputies 'plateaued', unavailed (James and Whiting, 1998) or career deputies. Resnatronic is a new name for this hitherto overlooked group. A resnatron is a tetrode valve with four electrodes used to generate high power at high frequencies - an excellent description of deputies' lives in English schools. The word recalibrates attitudes to elective deputies which is important when $44 \%$ of England's deputy principals do not want a principalship and over $50 \%$ are not actively seeking principalships (James and Whiting, 1998).

\section{Negatively Effective Follower Types}

Alienates withdraw from leader-follower relationships. They do not join decision making nor support leaders but seldom openly oppose them. They are disgruntled, recognisable as those 'muttering' during staff meetings, sitting with arms folded or eyes closed and contributing only such statements as 'We tried that before and it didn't work'. They are non-participants, getting by on the least work possible. Alienated followers are critical and independent in their thinking but passive in their work conduct. (Kelly, 1992; Sevier, 1999)

Isolates are 'going nowhere' (Joel, 1997, 7), choosing to be virtually outside the organization.

Dependants seek guidance and approval from leaders before actions but they may be just the immature effective followers (Bucholtz and Roth, 1987; Roe and Baker 1989).

Passives follow instructions, do not oppose anything nor indicate their support. They are neutral and disinterested, best typified as those who work precisely from 'nine-to-five'.

Observers are passive and will alter their allegiances according to whom they assess the likely winner to be as they watch what happens.

Reluctant-resistives are alienates who oppose the leader and publicly. Their resistance may be reluctantly expressed, e.g. 'I am sorry to have to disagree but...'. Leaders' suggestions will be politely received but not acted on or action will be significantly delayed.

Sheep are passive, uncritical, lack initiative, purpose and a sense of responsibility. At best they are able to perform the tasks assigned to them but then come to a stop (Kelly, 1988). 
Plateaued followers have travelled as far through the organization as they are likely to go but are not recognisably at 'the top' nor are they likely to get there, being precluded by ability, age or office politics. With no chance of personal development, plateaued followers are at best diligent but uninspired performers and at worst, under-performers and job-avoiders.

Machiavellians are slavish and unquestioning followers of leaders who ruthlessly exercise power, 'using guile and deception when expedient...[and showing] indifference to the concerns of others' (Owens, 1995, 122-3).

Survivors are “fence sitters” who adapt chameleon like to new conditions (Kelly, 1988).

Yes people are unenterprising being completely dependent on leaders for inspiration. They can be aggressively deferential sycophants (Roe and Baker, 1989).

\section{Negatively Effective Follower Roles}

These 'dark angels...addicts, crooks, fanatics, sociopaths - the organizational equivalent of the undead' (Robbins and Finley, 1998, 69), can be divided into:

Communication distorters deliberately warp messages from a leader, causing confusion and disaffection.

Saboteurs are either embittered followers who perceive themselves as having been badly treated by leaders or who consider that leaders are wrong or weak. They actively oppose their leaders (Sevier, 1999, 13) usually by covert micro-political tactics arising from their Machiavellian loyalty to an alternative leader but some are overtly domineering and demanding (Robbins and Finley, 1998). Saboteurs may camouflage themselves as leaders' friends so when illegal drugs are discovered in the technology laboratory on Parents' Evening, enquire after the Head of ICT who was handing the leader champagne just before the discovery.

Toxic creators encourage problems to grow rather than be solved and invent some if none is available.

\section{Why use this lexicon as a map?}

Developing the new area of followership for research arose from the author's questioning of the received wisdom that leadership is all that matters to success. This 'wisdom' overburdens leaders and fails to credit the effect of positive and negative followers.

The 2000s educational leaders are viewed as saviours able to rescue failing organizations or improve even good schools. This expectation leads to stress, resignations, dismissals and too few wanting to become principals despite much increased salaries (Statt, 1994; Chaplin, 2001). Leaders are raised 'to heights from which they can rarely fail to disappoint' (Gabriel, 1997: 316). A dependence culture results; followers do not take responsibility themselves because a messiah has come. Followers are intellectually and emotionally deskilled (Gemmill and Oakley, 1992:119). 
School inspections by England's Office for Standards in Education (OFSTED) reinforce over-reliance on leaders. Inspectors grade school leadership almost entirely based on their assessment of the school principal. Teachers are rated for their classroom duties towards children but not in their followership roles towards colleagues. When a school is rated as 'failing' then usually the principal has to resign, irrespective of the extent to which other staff may have failed to be exemplary followers. In England, the advent of the selfmanaging school over the last twenty years has further excerbated the over-expectations a leader. State school principals now have the dual roles of business and instructional leaders. If principals are to be saved from exhaustion, if we are to have more people applying for principalships, if we are to stop blaming one individual when a school fails, then we must elevate the status and roles of the followers.

This plea also recognises that followers provide a vital, psychological role in organizations. They represent the Jungian 'dark side' of leaders as their shadow personalities, working 'on the issues that the leader...keeps hidden and cannot engage directly...the shadow includes those aspects of the personality that we want to hide or disown' (Berg, 2001:9). A leader, therefore, operates much more effectively when there is a follower (or followers) who can be the public opposite of the leader, can absorb opprobrium that might otherwise be directed at the leader and can take on roles that might hamper the freedom of movement of the leader. This reinforces Chaleff's view of followers as courageous - brave enough to tell leaders what may be unwelcome news (Chaleff, 1995).

More prosaically, when all but leadership is denigrated, then organizations are in danger of not managing some of their basic needs. For example, advice to deputy principals or heads of departments, suggests that they should concentrate on leadership aspects such as strategy and people management; they should eschew such maintenance tasks as 'checking stock levels, ordering for the next academic year, planning and finalising courses, allocating students to groups, completing records and profiles and compiling lists' (Buckby, 1997, 25). So who, one wonders, is to do these - other, more lowly followers perhaps?

Despite the denigation of followership tasks, research claims that followers account for eighty per cent of an organization's success (Kelley, 1992:8) and that good leaders are made by good followers (Johnson 1981; O’Neill and Welland, 1986; Kouzes and Posner, 1990: 29; Atwater et al 1995; Fullan, 1995:21; Allinson et al 1999). School principals without majority support are powerless to effect change (Mortimore, 1996: 261).

Even less generally realized is that good followers are made by their contacts with other good followers irrespective of their leaders' attributes (Meindl, 1990). Wallace and Hall's 1994 study of senior management teams (SMTs) in English secondary schools showed that while the school principals decided what roles the team members should play, how these worked out in practice depended on how colleagues reacted to each other and not to the principals' intentions. In primary schools too, Wallace found that headteachers' powers to set an SMT's parameters were limited (2001, 161, 163). There is no evidence 'demonstrating stable and long-term effects of leaders on follower self-esteem, motives, desires, preferences or values' (House and Aditya, 1997:443). All this underlines the need to comprehend effective followership.

\section{Quo vadis adsectator ${ }^{3}$ ?}


Other languages can extend our followership lexicon Latin, for example, offers the positive adsectator (companion), the neutral successor (heir) and stipator (attendant) and negatives adsecula (servant, sycophant), pedisequus (lackey) and sectator (hanger on). The international conference audiences added more words from other languages. Developing empirical research will be easier now that the vocabulary of followership offers so many positive words with which research subjects might feel happy to ally themselves and a range that shows that followers have as much personal choice as leaders in how they behave.

\section{References}

Atwater, L., Roush, P. and Fischthal, A. (1995) 'The influence of upward feeling on self and follower ratings of leadership'. Personnel Psychology, 48 (1), 35-59.

Beatty, C.A. and Lee, G.L. (1992). Leadership among middle managers - an exploration in the context of technological change. Human Relations, 45 (9), 957-989.

Berg, D.N. (2001) Resurrecting the Muse: followership in organizations. www.sba.oakland.edu/ispso/html/berg.html:05/02/01. Intended for publication as a chapter in Klein, E.B. et al (Eds) New Paradigms for Leadership In the Twenty First Century. New Haven, CT: Yale University Press.

Boyd, N.G. and Taylor, R.R. (1998) 'A developmental approach to the examination of friendship in leader-follower relationships’. Leadership Quarterly, 9 (1) 1-25.

Brown, A. and Thornborrow, W.T. (1996) 'Do organizations get the followers they deserve?' Leadership and Organization, 17 (1) 5-11.

Brundrett, M. (1998) 'What lies behind collegiality, legitimation and control? : An Analysis of the Purported Benefits of Collegial Management in Education'. Educational Management and Administration, 26 (3) 305-316.

Buckby, R. (1997) 'Enhancing school effectiveness through heads of department', Management in Education, 11 (4) 25-8.

Bucholtz. S. and Roth, T. (1987) Creating the High Performance Team. New York: Wiley and Sons quoted in Roe, M.A. and Baker, G.A. (1989) 'The development of community college lecturers: a challenge for our future'. Community College Review, 16 (4) 5-16.

Bush, T. (1995) Theories of Education Management, (2nd Ed) London: PCP.

Chaleff, I. (1995) The courageous follower: standing up to our leaders, San Francisco: Berrett-Koehler.

Chaplin, R.P. (2001) 'Stress and Job Satisfaction among Primary Headteachers. A Question of Balance'. Educational Management and Administration, 29 (2):197-215.

Conger, J.A. (1999) 'Charismatic and transformational leadership in organizations: an insider's perspective on these developing streams of research'. Leadership Quarterly, 10 (2) $145-179$.

Eden, D. Geller, D., Gewirtz, A., Gordon-Terner, R., Inbar, I., Liberman, M., Pass, Y., Salomon-Segev, I. and Shalit, M. (2000) 'Implanting Pygmalion Leadership Style Through Workshop Training: Seven Field Experiments’. Leadership Quarterly, 11 (2) 171-210.

Ellis, T. (2003) Reconceptualising the secondary school as an organization. Unpublished PhD thesis, University of Lincoln, England.

Engel, M.V. (1997) 'The new non-managers', Management Quarterly, 38 (2) 22-29.

Evetts, J. (1993) 'LMS and Headship: Changing Contexts for Micro-Politics'. Educational Review, 45 (1) 53-65. 
Ferris, G.R., Fedor, D.B., Chachere, J.G. and Pondy, L.R. (1989) 'Myths and politics in organizational contexts', Group and Organizational Studies, 14, 83-103.

Frost, P. and Robinson, S. (1999) 'The Toxic Handler: Organizational Hero- and Casualty'. Harvard Business Review, July-August, p.97.

Fullan, M. (1995) The evolution of change and the new work of the educational leader, in Wong, K.C. and Cheng, K-M, Educational Leadership and Change. Hong Kong: Hong Kong University Press

Furnham, A. (1997) The Psychology of Behaviour at Work: The Individual and The Organization, Hove: Psychology Press.

Gabriel, Y. (1997) 'Meeting God: when organizational members come face to face with the supreme leader'. Human Relations, 50 (4) 315-333.

http://www.infotrac.galegro.../purl=rc1_EBA_0_A19490684\&dyn=11!ar_fmt?sw_aep=ul 20/11/00, pp.1-30.

Gardner, H. (1997). Leading Minds. London: HarperCollins

Gardner, W.L. and Avolio, B.J. (1998) Academy of Management Review, 23 (1) 32 - 59.

http://www.infotrac.galegro.../purl=rc1_EBA_0_A20421505\&dyn=8!ar_fmt?sw_aep=ul

20/11/00, pp.1-33.

Gemmill, G. and Oakley, J. (1992) 'Leadership: an Alienating Social Myth?', Human

Relations, 45 (2) 113-129.

Gronn, P. (1996) 'From Transactions to Transformations. A New World Order in the Study of Learning?', Educational Management and Administration, 24, (1) 9-30.

Gronn, P. (2000) 'Distributed Properties: a new architecture for leadership?', Educational Management and Administration, 28 (3) 317-338.

Holmes, C.M., Sholley, B.K. and Walker, W.E. (1980) 'Leader, Follower, and Isolate Personality Patterns in Black and White Emergent Leadership Groups'. Journal of Psychology, 105, 41-46.

Hoskins, D.M. (1988) 'Organizing, leadership and skilful process', Journal of

Management Studies, 25 (2) 147-166.

House, R.J. and Aditya, R.M. (1997) 'The social scientific study of leadership: Quo Vardis?’ Journal of Management, 23, 409-473.

James, C. and Whiting, D. (1998) Headship? No thanks! A study of factors influencing career progression to headship, Management in Education, 22, (2) 12-14.

Johnson, R. W. (1981) 'Leader-Follower Behavior in 3-D, Part 2'. Personnel, Sept.Oct., 50-61.

Kelley, Robert E. (1988) 'In Praise of Followers’. Harvard Business Review, Nov.-Dec., 142-148.

Kelley, Robert E. (1992) The Power of Followership. New York, Doubleday.

Kouzes, J.M. and Posner, B.Z. (1990) 'The credibility factor: what followers expect from their leaders', Management Review, 79 (1) 29-34.

Lakomski, G. (1999) Against Leadership: a concept without a cause. In P. Begley and P. Leonard (Eds) The Values of Educational Administration, London: Falmer.

Madison, D.L., Allen, R.W., Porter, L.W., Renwick, P.A. and Mayes, B.T. (1980) 'Organizational politics: an exploration of managers' perceptions' Human Relations, 33 (2) $79-100$.

Meindl, J.R. (1990). On Leadership: An Alternative to the Conventional Wisdom. In B.M. Staw and L.L.Cummings (eds) Research in Organizational Behavior, 12. Greenwich, CT: JAI Press.

Miner, J.B. (1975) 'The Uncertain Future of the Leadership Concept: an Overview'. In J.G Hunt and L.L.Larson (eds) Leadership Frontiers, Kent OH: Kent State University Press. 
Mintzberg, H. (1985) 'The organization as a political arena', Journal of Management Studies, 22 (2) 133-154.

Mortimore, P. (1996) 'The School as a Community of Learners', Leading and Managing, 2 (4) 251-266.

Nelson, D., Basu, R. and Purdie, R. (1998) 'An Examination of Exchange Quality and Work Stressors in Leader-Follower Dyads'. International Journal Of Stress Management, 5 (2) 103-112.

O’Neill, A. and Welland, R. (1986) 'Leadership and academic governance in a college of advanced education'. Journal of Educational Administration, 24 (1) 122-134.

O’Sullivan, F., Thody, A.M. and Wood, E. (2000) From Bursar to School Business Manager, London, Financial Times Publishing.

Ouston, J. (1993) Women as managers, in Ouston, J. (ed) (1993) Women in education management, Harlow: Longman

Owens, R.G. (1995) Organizational Behaviour in Education. Allyn and Bacon: Boston.

Petersen, George J. and Beekley, Cynthia X. (1997) 'School Principals' Understanding of the Follower-Leader Relationship in District Management'. Article presented at the Annual Conference of the University Council of Educational Administration, Orlando, Florida, USA.

Pratt, S. (1984). Subordinates' Strategies of Interaction in the Management of Schools, in P. Harling (ed) New Directions in Educational Leadership. London: Falmer.

Robbins, H. and Finley, M. (1998) The People Problem. In Robbins, H. and Finley, M. Why Teams Don't Work: what went wrong and how to make it right'. London: Onion Publishing.

Sevier, R. (1999) 'How to be an exceptional follower'. Trusteeship, 7 (1) 12-17.

Simkins, T. (1999) 'Values, Power and Instrumentality', Educational Management and Administration, 27 (3) 267-281.

Statt, D.A. (1994) Psychology and the World of Work. Basingstoke: Macmillan.

Steven, W.F. and Woolridge, B. (1997). Middle Management's Strategic Influence and Organizational Performance. Journal of Management Studies, 34 (3) 465-485.

Thody, A.M. (Ed) (1994) School Governors: Leaders or Followers ? Harlow, Longmans Thody, A.M. (1997) 'Challenge, change and continuity: an exploration of developments in leadership and followership', in D'Arbon, T. (Ed) Pathways to Educational

Administration,, Melbourne: ACEA

Thody, A.M. (2000) 'Followership or followersheep? 2000 An Exploration of the Values of Non-Leaders', Management in Education, 14 (2) 15-18.

Thody, A.M. (2001) 'Non-leadership and children's leadership skills'. Unpublished conference article, Universities’ Council For Educational Administration, USA.

Valikangas, L. and Okumura, A. (1997) 'Why do people follow leaders? A study of a U.S. and Japanese change program’. Leadership Quarterly, 8 (3) 313-337.

Volgelaar, Ad L.W. and Kuipers, H. (1997) ' Reciprocal Longitudinal Relations Between Leader and Follower Effectiveness’. Military Psychology, 9 (3) 199-212.

Wallace, M and Hall, V. (1994) Inside the SMT: Teamwork in Secondary School Management. London, Paul Chapman.

Wallace, M. (2001) 'Sharing Leadership of Schools through Teamwork. A Justifiable Risk?’. Educational Management and Administration, 29 (2) 153-167.

Williams, V. (1998) 'Leader and follower relationships:Emerging perceptions about the conceptual nature of followership in education' in Van Der Bogert, R. and Williams, V. (eds) Conceptual and Practical Issues in School Leadership, San Francisco, Jossey-Bass. 
${ }^{1}$ Brinley Morgan, IIEl Research Associate, assisted with the early literature searches.

${ }^{2}$ For the purposes of this article, effectiveness is taken to mean 'contributing to the success of an organization'.

${ }^{3}$ Whither goest thou, follower?' 